\title{
Growth and Fruit Yield of Hybrid Ridge Gourd [Luffa acutangula L. Roxb] Arka Vikram in Relation to NPK Fertigation
}

\author{
H.C. Ananda Murthy ${ }^{1 *}$, A.K. Nair ${ }^{2}$, M. Anjanappa ${ }^{1}$, D. Kalaivanan ${ }^{3}$, S. Shankara \\ Hebbar $^{4}$ and R.H. Laxman \\ ${ }^{1}$ Department of Vegetable Science, $\mathrm{COH}$, Bengaluru, India \\ ${ }^{2}$ Division of Vegetable Crops, ICAR-IIHR, Bengaluru, India \\ ${ }^{3}$ Division of Soil Science and Agricultural Chemistry, ICAR-IIHR, Bengaluru, India \\ ${ }^{4}$ Division of Vegetable Crops, IIHR, Bengaluru, India \\ ${ }^{5}$ Division of Plant Physiology and Biochemistry, ICAR-IHR, Bengaluru, India \\ *Corresponding author
}

\section{Keywords}

Ridge gourd,

Fertigation, Water

soluble fertilizers,

Growth, Yield

attributing

characters and fruit yield

\section{Article Info}

Accepted:

30 May 2020

Available Online:

10 June 2020

\begin{abstract}
A B S T R A C T
A field experiment was conducted during 2018-2019 at Vegetable Research Block of ICAR-Indian Institute of Horticultural Research, Hessarghatta, Bengaluru, Karnataka to study the effect of fertigation with different levels of NPK on growth, fruit yield and quality of hybrid ridge gourd [Luffa acutangula (L.) Roxb] Arka Vikram. The experiment was laid out with eight treatments in randomized complete block design and replicated thrice. The results of the experiment revealed that the treatment $\mathrm{T}_{3}$ i.e application of water soluble fertilizers @ 150:90:150 kg NPK ha ${ }^{-1}$ through fertigation recorded maximum vine length $(635.31 \mathrm{~cm})$, internodal length $(14.52 \mathrm{~cm})$, number of leaves per vine (239.60), leaf area per vine $\left(6263.78 \mathrm{~cm}^{2}\right)$, number of female and male flower per vine (29.73 and 304.93) at 90 days after transplanting, number of fruits per vine (19.68), fruit length $(49.76 \mathrm{~cm})$, fruit girth $(18.40 \mathrm{~cm})$, average fruit weight $(454.03 \mathrm{~g})$, fruit yield per vine $(4.03 \mathrm{~kg})$ and fruit yield per hectare $\left(53.73 \mathrm{t}\right.$ ). Fertigation with water soluble fertilizers (Urea, 19:19:19 and $\mathrm{KNO}_{3}$ ) ( 150:90:150 kg NPK ha-1 increased the growth and fruit yield of hybrid ridge gourd significantly over reduced quantity of NPK applied with water soluble fertilizers, fertigation with common fertilizers and soil application of NPK fertilizers (Urea, SSP and MOP) @ 100:60:100 kg NPK ha ${ }^{-1}$. From this investigation, it may be concluded that fertigation of water soluble fertilizers (Urea, 19:19:19 and $\mathrm{KNO}_{3}$ ) @ 150:90:150 kg NPK ha ${ }^{-1}$ is good for getting maximum growth, yield attributing characters and yield of hybrid ridge gourd Arka Vikram.
\end{abstract}

\section{Introduction}

Ridge gourd [Luffa acutangula (L.) Roxb.], popularly known as angled gourd, angled loofah, Chinese okra, silky gourd, ribbed gourd and Kalitori or Herakayi locally, belongs to genus Luffa of "Cucurbitaceae" family. The genus derives its name from the product "loofah" which is used in bathing sponges, scrubber pads, door mats, pillows, mattresses and also for cleaning utensils. Ridge gourd is known to have originated in India and is cultivated in the tropics and subtropics for its tender edible fruits both on commercial scale and in kitchen gardens throughout the country and in some parts of 
Indonesia, Myanmar, Malaysia, Philippines, Sri Lanka and Taiwan. The tender fruits of ridge gourd are green in colour, which are used in various culinary items. The gourd fruit contains a gelatinous compound "luffein" which is emetic and traditionally used for a treatment of stomach ailment and fever (Karthick et al., 2017).

India has produced 187.47 million tonnes of vegetables from an area of 10.4 million hectares in 2017-2018 securing the second place among the vegetable producing countries of the world (NHB, 2019). The vegetable requirement for the country has been estimated 225 million tonnes by 2020 21. To achieve this target and to provide balanced diet it is necessary to boost up the production of vegetables by increasing area, use of improved technologies and by developing and using high yielding varieties (Anil Kumar and Dwivedi, 2018). The statistical data on most of the cucurbitaceous vegetables with respect to area and production are not available, however squashes and gourds as a group of vegetables has been estimated to occupy an area of 3,632 hectares in Karnataka with a production of 34,683 tonnes and productivity of 9.54 tonnes per hectare (NHB, 2014-15).

Balanced nutrition is one of the important factor affecting the growth and productivity of vegetable crops. The optimum levels at which the nutrients are to be applied and source from which they have derived are equally important. Excessive use of fertilizers for increasing the crop yields will lead to nutrient leaching which ultimately affects the soil and environmental health besides increasing cost of production (Hebbar et al., 2004). Fertigation is an effective means of controlling timing and placement of fertilizers and improving fertilizer use efficiency by reducing losses through leaching, volatilization and fixation in the soil to less available forms (Papadopoulos, 1995). Scientific information on fertigation especially on ridge gourd is very less; hence, the present study was conducted to find out the optimum fertigation doses for better growth, yield and fruit quality of hybrid Ridge gourd Arka Vikram.

\section{Materials and Methods}

The field experiment was conducted during 2018-2019 (September 2018 to February 2019) at the Vegetable Research Block of ICAR-Indian Institute of Horticultural Research, Hessarghatta, Bengaluru, which is situated in Eastern dry zone of Karnataka state at 890 meters above mean sea level. It comes under Zone-5 of region-3 among the Agro-Climatic Zones of Karnataka and has the benefit of both South West and North East monsoons. The normal rainfall of this area is about $800 \mathrm{~mm}$, distributed over a period of six to seven months (May-November) with peaks during September. The soil type of the experimental site was well drained red sandy loam having initial organic carbon (1.06\%), $\mathrm{pH}(6.75)$, electrical conductivity $\left(0.23 \mathrm{dSm}^{-}\right.$ $\left.{ }^{1}\right)$, available nitrogen (171.92 $\left.\mathrm{kg} \mathrm{ha}^{-1}\right)$, available phosphorus (34.69 $\left.\mathrm{kg} \mathrm{ha}^{-1}\right)$ and available potassium $\left(217.29 \mathrm{~kg} \mathrm{ha}^{-1}\right)$. The 16 days old seedlings of ridge gourd hybrid "Arka Vikram" were transplanted at $1.50 \mathrm{x}$ $0.50 \mathrm{~m}$ spacing during the first week of October in 2018. Ridge gourd hybrid named "Arka Vikram" was identified and released by the ICAR-IIHR during 2016. It has the character of early flowering. The first female flower takes 40 days to appear on $9^{\text {th }}$ node from the base of vine and 46 days for first picking of fruits. This hybrid produces green, long and tender fruits. It has excellent cooking quality, nutritionally rich in antioxidant activity and minerals like potassium, calcium, iron, zinc and manganese. It yields around $34.0 \mathrm{t} \mathrm{ha}^{-1}$ in 120-135 days duration. 
The experiment was laid out in randomized complete block design with eight treatments, which was replicated thrice. The farm yard manure@25 tonnes and neem cake@625 $\mathrm{kg}$ per hectare was applied uniformly to all the treatments. The treatment details and the amount of fertilizers applied treatment wise are given in Table 1. The fertilizers were applied based on fertigation treatments in the form of water soluble fertilizers (urea, 19:19:19 and potassium nitrate) and conventional fertilizers (urea, di-ammonium phosphate and muriate of potash). For soil application treatment conventional fertilizers viz., urea, single super phosphate and muriate of potash were applied, where, entire $\mathrm{P}$ and half of $\mathrm{N}$ and $\mathrm{K}$ were given as basal and remaining half of $\mathrm{N}$ and $\mathrm{K}$ was side dressed at $30^{\text {th }}$ and $60^{\text {th }}$ days after transplanting in equal splits. In other treatments, fertigation was started two weeks after transplanting and given at weekly interval. Various growth and yield parameters were recorded from five plants selected randomly replication wise in all the treatments. All the agronomic and plant protection measures were adopted as per the recommended package of practices (Prabhakar et al., 2010). The experimental data were statistically analysed (Panse and Sukhatme, 1978) and compared using critical difference at five per cent probability level.

\section{Results and Discussion}

\section{Growth characters}

The data pertaining to plant growth characters are presented in Table-2. The perusal of the data clearly indicated that different treatments significantly influenced all the growth characters recorded at 90 days after transplanting. The vines were significantly longer with $\mathrm{T}_{3}$ i.e. fertigation with water soluble fertilizers @ 150:90:150 kg NPK ha ${ }^{-1}$ $(635.31 \mathrm{~cm})$ than all other treatments, but it remained on par with the treatment, where the fertigation was given using water soluble fertilizers @ 125:75:125 kg NPK ha ${ }^{-1}$ $(623.47 \mathrm{~cm})$. Similarly the same treatment i.e. $\mathrm{T}_{3}$ recorded significantly higher values for intermodal length $(14.52 \mathrm{~cm})$, which remained on par with $\mathrm{T}_{2}(13.57 \mathrm{~cm})$ and $\mathrm{T}_{8}$ $(13.85 \mathrm{~cm})$. The shortest vine $(469.78 \mathrm{~cm})$ and intermodal length $(12.33 \mathrm{~cm})$ recorded in fertigation with conventional fertilizers @ 100:60:100 kg NPK ha ${ }^{-1}$. In case of number of leaves per vine, significantly higher values were recorded with $\mathrm{T}_{3}$ (239.60) than all other treatments and same treatment also recorded significantly higher leaf area per vine $\left(6263.78 \mathrm{~cm}^{2}\right)$ but remained on par with $\mathrm{T}_{8}, \mathrm{~T}_{2}$ and $\mathrm{T}_{1}$. The significantly lowest number of leaves and leaf area per vine recorded with $\mathrm{T}_{6}$ (139.53) and $\mathrm{T}_{5}\left(4309.23 \mathrm{~cm}^{2}\right)$, respectively, where the lower amount of water soluble fertilizers were applied through fertigation. Frequent supplying of the fertilizers through drip irrigation in the vicinity of root zone to meet the nutritional requirement of crop lead to maximum absorption and translocation of nutrients, which resulted in increased cell size, cell elongation, cell multiplication and enhanced net assimilation rate might be the reason for more number of leaves, leaf area etc. These results were in accordance with Feleafel and Mirdad (2013), Ughad et al., (2015) and Nayak et al., (2018). Nitrogen is being a very important constituent of chlorophyll, proteins and enzymes and has a prominent role in increasing the cell size and cell division, which produces the longer vines, more number of leaves and leaf area. Phosphorus is being a very essential nutrient for root development and is required for better utilization of the increased nitrogen dose (Marschner, 1995). It enhances the photosynthetic efficiency of the plant, when supplied during early growth stages of the crop (Tisdale et al., 1985). Finally potassium plays a major role in enhancing the photosynthetic activity and translocation of carbohydrates for development of the aerial 
parts. Similar results were also reported by Singandhupe et al., (2007), Ram et al., (2013) in pointed gourd and Sikarwar and Hardaha (2016) in poly house grown cucumber.

\section{Flowering characters}

Days taken for first female appearance, fifty per cent flowering and fruit setting to maturity are the traits associated with earliness in a crop. All these characters have shown significant differences for different treatments in hybrid ridge gourd (Table 3). Application of water soluble fertilizers @ 150:90:150 kg NPK ha ${ }^{-1}$ through fertigation resulted in minimum number of days taken for first female flower appearance (36.33), which remained on par with $\mathrm{T}_{2}(36.90)$ and $\mathrm{T}_{1} \& \mathrm{~T}_{8}$ (37.33). Application of water soluble fertilizers @ 50:30:50 kg NPK ha ${ }^{-1}$ took maximum days for the appearance of first female flower (39.66). The treatment $\mathrm{T}_{3}$ took significantly minimum number of days to fifty per cent flowering (43.20) compared to all other treatments, while $\mathrm{T}_{5}$ had maximum number of days (47.60) for the same character. Significantly minimum days taken from fruit setting to maturity (6.13) also recorded in $\mathrm{T}_{3}$, followed by $\mathrm{T}_{2}(6.73), \mathrm{T}_{1}$ and $\mathrm{T}_{8}$ (6.93), while $\mathrm{T}_{5}$ took maximum days (7.93). Application of water soluble fertilizers @ 150:90:150 kg NPK ha ${ }^{-1}$ through fertigation also resulted in producing significantly higher number of female flowers per vine (20.67) than all the treatments. The minimum number of female flowers per vine was observed with $\mathrm{T}_{7}$ (22.13). There were no significant differences among the treatments for the number of male flowers per vine. However, $\mathrm{T}_{3}$ recorded the maximum number of male flowers (304.93) followed by $\mathrm{T}_{8}$ (265.27), $\mathrm{T}_{4}$ (245.33) and $\mathrm{T}_{1}$ (238.27).

It has been observed that application of higher amount of fertilizers have resulted in higher values for most of the flower related characters. At higher fertigation level better availability of sufficient quantity of nutrients especially the applied higher dosage of nitrogen, phosphorus and potassium to the plants in water soluble form may have resulted in early appearance of female flowers. The results are in confirmation with Choudhari and More (2002), Jilani et al., (2009), Sharma et al., (2009), Shinde et al., (2010) in cucumber and Kumar et al., (2018) in ridge gourd. This may also be attributed to the reason that increased leaf area produced high levels of assimilates in the photosynthetic process which hastened the appearance of female flower. The increase in the number of early appearance of female flowers per vine made the $\mathrm{T}_{3}$ plant populations to take minimum days for $50 \%$ flowering and fruit setting to maturity (Karthick et al., 2017).

\section{Yield and quality attributing characters}

Yield and quality attributing characters were influenced significantly by different treatments and data are presented in Table-4. Application of water soluble fertilizers @ 150:90:150 kg NPK ha ${ }^{-1}$ through fertigation $\left(\mathrm{T}_{3}\right)$ recorded higher number of fruits (19.68) per vine than other treatments. The second highest and minimum number of fruits per vine was recorded in $\mathrm{T}_{2}$ (16.55) and $\mathrm{T}_{5}$ (13.90), respectively. The increase in number of fruits might be due to increase in number of female flowers on account of increased number of primary and secondary branches either due to increased nitrogen or potash. It was also reported by Parmar et al., (2011) in cucumber. The higher number of female flowers and branches per plant could be also attributed to the higher fruit number. Similar findings are obtained by Shinde et al., (2010) in cucumber, Rani et al., (2012), Nayak et al., (2018) in pointed gourd and Anil Kumar and Dwivedi (2018) in ridge gourd (Fig. 1). 
Table.1 Treatment details and amount of fertilizers applied under different treatments $\left(\mathrm{kg} \mathrm{ha}^{-1}\right)$

\begin{tabular}{|c|c|c|c|c|c|c|c|}
\hline Symbol & Treatment & Urea & 19 all & $\mathrm{KNO}_{3}$ & SSP & DAP & MOP \\
\hline$T_{1}$ & $\begin{array}{l}\text { Fertigation with water soluble fertilizers } \\
\text { @ 100:60:100 kg NPK ha }\end{array}$ & 62.00 & 316.00 & 89.00 & - & - & - \\
\hline $\mathbf{T}_{2}$ & $\begin{array}{l}\text { Fertigation with water soluble fertilizers } \\
\text { @ 125:75:125 } \mathrm{kg} \mathrm{NPK} \mathrm{ha}^{-1}\end{array}$ & 77.50 & 395.00 & $\begin{array}{c}111.2 \\
5\end{array}$ & - & - & - \\
\hline $\mathbf{T}_{3}$ & $\begin{array}{l}\text { Fertigation with water soluble fertilizers } \\
\text { @ 150:90:150 } \mathrm{kg} \mathrm{NPK} \mathrm{ha}^{-1}\end{array}$ & 93.00 & 474.00 & $\begin{array}{c}133.5 \\
0\end{array}$ & - & - & - \\
\hline $\mathbf{T}_{4}$ & $\begin{array}{l}\text { Fertigation with water soluble fertilizers } \\
\text { @ 75:45:75 kg NPK ha- }\end{array}$ & 47.00 & 237.00 & 66.75 & - & - & - \\
\hline $\mathbf{T}_{5}$ & $\begin{array}{l}\text { Fertigation with water soluble fertilizers } \\
\text { @ 50:30:50 kg NPK ha }\end{array}$ & 31.00 & 158.00 & 44.50 & - & - & - \\
\hline $\mathbf{T}_{6}$ & $\begin{array}{l}\text { Fertigation with water soluble fertilizers } \\
\text { @ 50:50:50 kg NPK ha }\end{array}$ & - & 263.00 & - & - & - & - \\
\hline $\mathbf{T}_{7}$ & $\begin{array}{l}\text { Fertigation with normal fertilizers @ } \\
\text { 100:60:100 kg NPK ha }\end{array}$ & $\begin{array}{c}166.2 \\
0\end{array}$ & - & - & & 130.00 & $\begin{array}{c}167.0 \\
0\end{array}$ \\
\hline$T_{8}$ & $\begin{array}{l}\text { Soil application of NPK fertilizers @ 100:60:100 } \\
\mathrm{kg} \mathrm{NPK} \mathrm{ha}^{-1}\end{array}$ & $\begin{array}{c}217.0 \\
0\end{array}$ & - & - & $\begin{array}{c}375.0 \\
0\end{array}$ & - & $\begin{array}{c}167.0 \\
0\end{array}$ \\
\hline
\end{tabular}

19 all: 19:19:19 $\mathrm{KNO}_{3:}$ Potassium Nitrate SSP: Single Super Phosphate DAP: Di- ammonium phosphate MOP: Muriate of Potash

Table.2 Effect of fertigation treatments on growth characters at 90 days after planting in hybrid ridge gourd

\begin{tabular}{|c|c|c|c|c|}
\hline Treatments & $\begin{array}{c}\text { Vine length } \\
\text { (cm) }\end{array}$ & $\begin{array}{c}\text { Internodal } \\
\text { length } \mathbf{( c m )}\end{array}$ & $\begin{array}{c}\text { Number of } \\
\text { leaves per } \\
\text { vine }\end{array}$ & $\begin{array}{c}\text { Leaf area } \\
\text { per vine } \\
\text { (cm } \mathbf{2}\end{array}$ \\
\hline $\mathbf{T}_{\mathbf{1}}$ & 545.89 & 13.25 & 184.80 & 5923.28 \\
\hline $\mathbf{T}_{\mathbf{2}}$ & 623.47 & 13.57 & 207.73 & 6039.63 \\
\hline $\mathbf{T}_{\mathbf{3}}$ & 635.31 & 14.52 & 239.60 & 6263.78 \\
\hline $\mathbf{T}_{\mathbf{4}}$ & 546.50 & 13.36 & 173.27 & 5441.49 \\
\hline $\mathbf{T}_{\mathbf{5}}$ & 490.49 & 13.12 & 163.20 & 4209.23 \\
\hline $\mathbf{T}_{\mathbf{6}}$ & 516.08 & 13.33 & 139.53 & 4647.97 \\
\hline $\mathbf{T}_{\mathbf{7}}$ & 469.78 & 12.33 & 158.73 & 5150.73 \\
\hline $\mathbf{T}_{\mathbf{8}}$ & 579.11 & 13.85 & 211.80 & 6205.48 \\
\hline S.Em $\mathbf{E}$ & 10.00 & 0.37 & 6.24 & 190.14 \\
\hline C.D. @ 5\% & 31.00 & 1.13 & 19.10 & 576.80 \\
\hline
\end{tabular}


Table.3 Effect of fertigation treatments on flowering characters in hybrid ridge gourd

\begin{tabular}{|c|c|c|c|c|c|}
\hline Treatments & $\begin{array}{c}\text { Number of } \\
\text { female } \\
\text { flowers per } \\
\text { vine }\end{array}$ & $\begin{array}{c}\text { Number of } \\
\text { male } \\
\text { flowers per } \\
\text { vine }\end{array}$ & $\begin{array}{c}\text { Days taken } \\
\text { for } \\
\text { first female } \\
\text { flower }\end{array}$ & $\begin{array}{c}\text { Days to 50 } \\
\text { percent } \\
\text { flowering }\end{array}$ & $\begin{array}{c}\text { Days taken } \\
\text { from fruit } \\
\text { setting } \\
\text { to maturity }\end{array}$ \\
\hline $\mathbf{T}_{\mathbf{1}}$ & 25.80 & 238.27 & 37.33 & 45.53 & 6.93 \\
\hline $\mathbf{T}_{\mathbf{2}}$ & 26.60 & 185.73 & 36.90 & 44.20 & 6.73 \\
\hline $\mathbf{T}_{\mathbf{3}}$ & 29.73 & 304.93 & 36.33 & 43.20 & 6.13 \\
\hline $\mathbf{T}_{\mathbf{4}}$ & 23.93 & 245.33 & 38.33 & 45.73 & 7.73 \\
\hline $\mathbf{T}_{\mathbf{5}}$ & 20.67 & 207.00 & 39.66 & 47.60 & 7.93 \\
\hline $\mathbf{T}_{\mathbf{6}}$ & 22.53 & 212.00 & 39.33 & 46.26 & 7.80 \\
\hline $\mathbf{T}_{\mathbf{7}}$ & 22.13 & 236.33 & 38.66 & 46.33 & 7.80 \\
\hline $\mathbf{T}_{\mathbf{8}}$ & 25.40 & 265.27 & 37.33 & 44.80 & 6.93 \\
\hline S.Em $\mathbf{E}$ & 1.26 & 7.48 & 0.35 & 0.28 & 0.31 \\
\hline C.D. @ 5\% & 3.88 & $\mathrm{NS}$ & 1.08 & 0.86 & 0.97 \\
\hline
\end{tabular}

Table.4 Effect of fertigation treatments on yield and fruit quality characteristics in hybrid ridge gourd

\begin{tabular}{|c|c|c|c|c|c|c|}
\hline Treatments & $\begin{array}{c}\text { Number of } \\
\text { fruits per } \\
\text { vine }\end{array}$ & $\begin{array}{c}\text { Fruit } \\
\text { length } \\
\text { (cm) }\end{array}$ & $\begin{array}{c}\text { Fruit } \\
\text { girth } \\
\text { (cm) }\end{array}$ & $\begin{array}{c}\text { Average } \\
\text { fruit } \\
\text { weight } \\
\text { (g) }\end{array}$ & $\begin{array}{c}\text { Fruit } \\
\text { yield } \\
\text { per vine } \\
\text { (kg) }\end{array}$ & $\begin{array}{c}\text { Fruit } \\
\text { yield } \\
\text { (t ha }\end{array}$ \\
\hline $\mathbf{T}_{\mathbf{1}}$ & 15.47 & 44.38 & 17.72 & 422.17 & 3.06 & 42.10 \\
\hline $\mathbf{T}_{\mathbf{2}}$ & 16.55 & 47.23 & 20.05 & 431.42 & 3.26 & 43.40 \\
\hline $\mathbf{T}_{\mathbf{3}}$ & 19.68 & 49.76 & 18.40 & 454.03 & 4.03 & 53.73 \\
\hline $\mathbf{T}_{\mathbf{4}}$ & 15.17 & 42.97 & 16.69 & 363.57 & 3.09 & 40.80 \\
\hline $\mathbf{T}_{\mathbf{5}}$ & 13.90 & 44.56 & 18.17 & 348.87 & 2.40 & 31.90 \\
\hline $\mathbf{T}_{\mathbf{6}}$ & 14.95 & 42.06 & 16.81 & 360.55 & 2.69 & 35.80 \\
\hline $\mathbf{T}_{\mathbf{7}}$ & 14.37 & 44.83 & 17.68 & 373.21 & 2.56 & 34.10 \\
\hline $\mathbf{T}_{\mathbf{8}}$ & 16.20 & 49.11 & 18.03 & 408.69 & 3.16 & 36.50 \\
\hline $\mathbf{S . E m \pm}$ & 0.77 & 0.85 & 0.48 & 22.55 & 0.16 & 0.61 \\
\hline C.D. @ 5\% & 2.37 & 2.62 & 1.49 & 69.06 & 0.49 & 1.88 \\
\hline
\end{tabular}



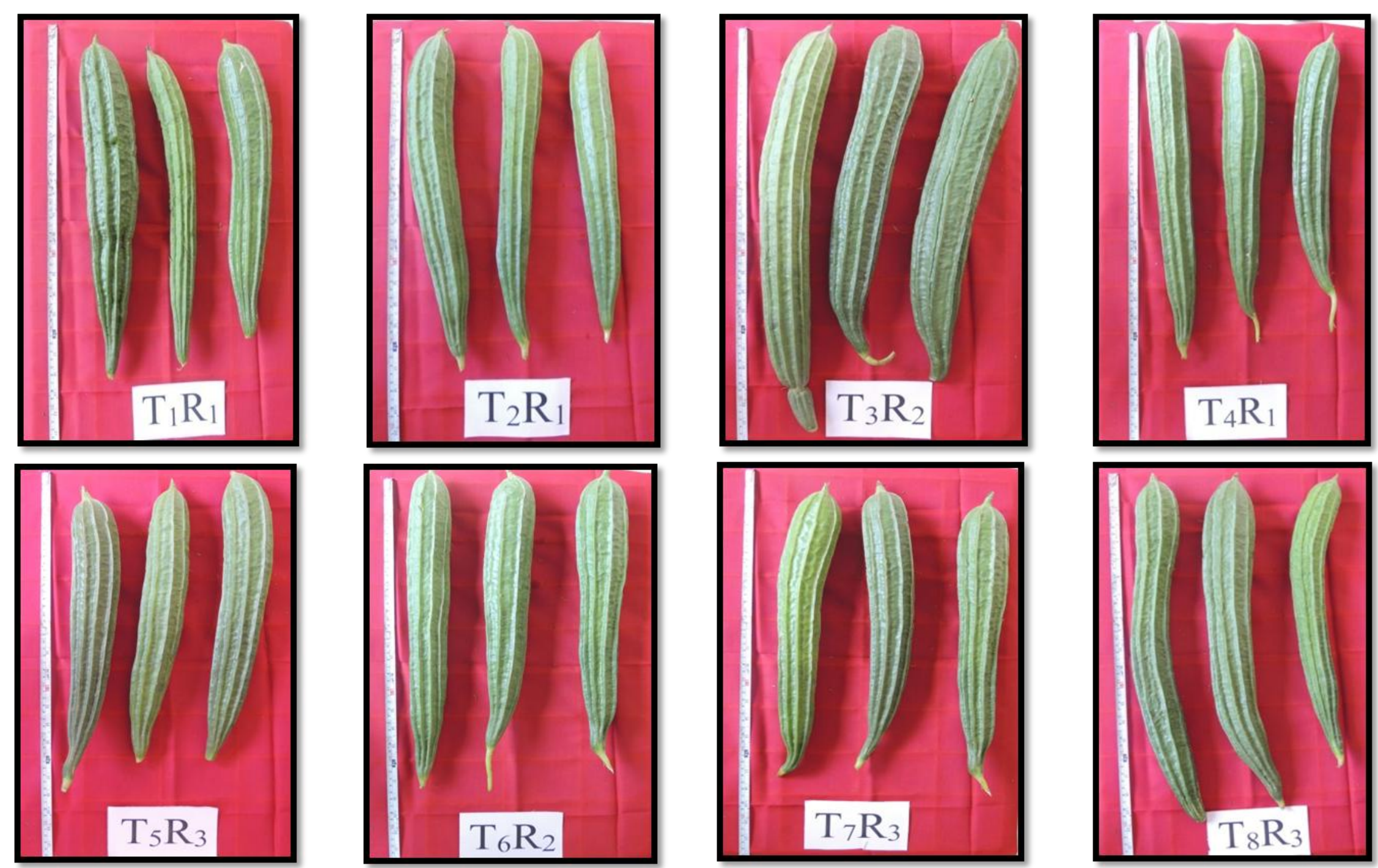

Fig.1 Effect of fertigation on fruit quality characters in hybrid ridge gourd Arka Vikram 
Similarly, longer fruits were also recorded with $\mathrm{T}_{3}(49.76 \mathrm{~cm})$, which remained on par with $\mathrm{T}_{8}(49.11 \mathrm{~cm})$ and $\mathrm{T}_{2}(47.23 \mathrm{~cm})$ only. Fruit girth was higher with $\mathrm{T}_{2}$ i.e. application of 100:60:100 kg NPK ha ${ }^{-1}$ using water soluble fertilizers through fertigation (20.05 $\mathrm{cm})$. The shortest and thinnest fruits were recorded with $\mathrm{T}_{6}(42.06 \mathrm{~cm})$ and $\mathrm{T}_{4}(16.69$ $\mathrm{cm})$. Increased nutrition to the vines with increase in levels of nitrogen and increased synthesis of chlorophyll and amino acids helped in efficient uptake resulting in increased length of the fruits. The similar findings were reported by Rodriguez et al., (2007), Sharma et al., (2009), Rasul et al., (2004) and Anil Kumar and Dwivedi (2018) in ridge gourd. The average fruit weight was maximum with $\mathrm{T}_{3}(454.03 \mathrm{~g})$, followed by $\mathrm{T}_{2}$ (431.42g), $\mathrm{T}_{1}\left(422.17 \mathrm{~g}\right.$ ) and $\mathrm{T}_{8}(408.69 \mathrm{~g})$. This may be due to the increase in fruit length and girth and also due to increased nutrition to the vines with increase in levels of nitrogen and increased synthesis of chlorophyll and amino acids. Similar differences in fruit size in kakrol strains / cultivars were also reported by Rasul et al., (2004). Fruit yield per wine was maximum in $\mathrm{T}_{3}(4.03 \mathrm{~kg})$ than all other treatments. The second highest value for the same was recorded with $\mathrm{T}_{8}(3.16 \mathrm{~kg})$. The higher level of fertigation, which had made the plants to respond in production of higher flowers per plant and percent of fruit set again, has helped in obtaining the highest fruit yield per plant. This is similar to the results reported by Papadopoulos (1986), Choudhari and More (2002), Manohar (2002) and Sharma et al., (2009).

Application of water soluble fertilizers @ 150:90:150 kg NPK ha ${ }^{-1}$ through fertigation $\left(T_{3}\right)$ recorded significantly higher fruit yield per hectare (53.73), which was higher to the tune of 23.8 to 70.4 per cent than other treatments tested in hybrid ridge gourd. The second highest fruit yield was obtained with $\mathrm{T}_{2}\left(43.40 \mathrm{t} \mathrm{ha}^{-1}\right)$ followed by $\mathrm{T}_{1}\left(42.10 \mathrm{tha}^{-1}\right)$.
It is evident from the data that application of lower amount of water soluble fertilizers through fertigation reduced the yield substantially (31.90 to $35.80 \mathrm{t} \mathrm{ha}^{-1)}$ compared to the best treatment (150:90:150 kg NPK ha ${ }^{-1}$ through fertigation). Application of water soluble fertilizers@50:30:50 kg NPK ha ${ }^{-1}$ resulted in minimum fruit yield of $31.90 \mathrm{t} \mathrm{ha}^{-}$ ${ }^{1}$. The highest fruit yield per hectare is due to more number of fruits per plant, fruit weight as well as increased fruit yield per plant. This increase in yield might have been due to the better performance of yield attributes as these attributes have a positive influence on the yield (Rani et al., (2012). The results of yield were in conformity with those of Wang et al., (2011) in watermelon, Rani et al., (2012) and Ram et al., (2013) in pointed gourd, Kayande et al., (2016) in bitter gourd, Sikarwar and Hardaha (2016) in cucumber and Anil Kumar and Dwivedi (2018) in ridge gourd.

From the study results, it is concluded that the highest growth and yield and better fruit quality of ridge gourd hybrid Arka Vikram could be obtained with fertigation of water soluble fertilizers @ 150:90:150 kg NPK ha ${ }^{-1}$. Further, fertigation with water soluble fertilizers (WSF) found to improve the growth, yield and fruit quality of ridge gourd compared to fertigation and soil application with normal fertilizers.

\section{Acknowledgement}

The authors are grateful to the Director, ICAR-Indian Institute of Horticultural Research, Hesaraghatta Lake Post, Bengaluru for providing support and necessary facilities during the course of this investigation.

\section{References}

Anil Kumar and Dwivedi, A.K. 2018. Growth and Yield of Ridge Gourd [Luffa acutangula L.(Roxb.)] as affected by application of nitrogen and potash fertilizers under agro- 
climatic condition of zone prevailing in Bokaro district of Jharkhand., Int. J. curr. Microbiol. App. Sci., 8: 22-28.

Choudhari, S. M. and More T. A. 2002. Fertigation, fertilizer and spacing requirement of tropical gynoecious cucumber hybrids. Acta Hortic., 588: 233-240.

Feleafel, M. N. and Mirdad, Z. M. 2013. Optimizing the nitrogen, phosphorus and potash fertigation rates and frequency for eggplant in arid regions. Int. J. Agril. Biol., 15(4): 737-742.

Hebbar, S. S., Ramachandrappa,B. K., Nanjappa, H. V. and Prabhakar, M. 2004. Studies on NPK drip fertigation in field grown tomato (Lycopersicon esculentum Mill.). European. J. Agron., 21: 117-127.

Jilani, M. S., Bakar, A., Waseem, K. and Kiran, M. 2009. Effect of different levels of NPK on the growth and yield of cucumber (Cucumis sativus) under the plastic tunnel. $J$. Agril. Soc. Sci., 5 (3): 99-101.

Karthick, K., Patel, G. S. and Prasad, J. G. R. 2017. Peformance of Ridge gourd (Luffa acutangula L. Roxb). varieties and nature of cultivation on growth and flowering attribute. Int. J. Agril. Sci., 9: 3910-3912.

Kayande, A., Kale, M. U., Wadatkar, S. B., Talokar, M. S. and Upadhye, S. K. 2016. Effect of polyethylene mulch on soil temperature. Asian. J. Soil. Sci., 11 (2): 332336.

Kumar, S., Dwivedi, Kumar, A., Krishna, G. and Karuna Kumari, K. 2018. Growth and Yield of Ridge Gourd [Luffa acutangula L. (Roxb.)] as affected by application of nitrogen and potash fertilizers under agroclimatic condition of zone prevailing in Jamtara district of Jharkhand Int. J. Curr. Microbiol. App. Sci., 8: 22-28.

Manohar, K. R. 2002. Evaluation of capsicum (Capsicum annuum) genotypes and effect of source of fertilizers and levels of fertigation under cost effective green house. Ph. $D$ (Agri.). Hort., Thesis submitted to UAS Bangalore.

Marschner, H. 1995. Mineral nutrition of higher plants. Academic Press Limited, Harcount, Brace Javanovich Pub., London Text Book., 155-193.

National Horticulture Board. 2014-15.
Horticultural statistics at a glance 2015, Ministry of Agriculture and Farmers Welfare, Government of India, pp. 12

National Horticulture Board. 2019. Horticultural statistics at a glance 2019, Ministry of Agriculture and Farmers Welfare, Government of India, pp. 14.

Nayak, H., Sahoo, D., Swain, S.C., Jena, B., Pradhan, P. and Paramjita, D. 2018. Effect of fertigation and mulching on growth, yield and yield attributing characteristics of pointed gourd (Trichosanthes dioica Roxb.) cv. Swarna Alaukik. IJCS, 6 (2): 258-261.

Panse, V. C., and Sukhatme. P. V. 1978. Statistical methods for Agricultural workers. III Rev. Ed. ICAR., New Delhi.

Papadopoulos, I. 1986. Nitrogen fertigation of greenhouse-grown cucumber. Plant and

Soil., 93: 87-93.

Parmar, M. K., Patel, B. L. and Mane, S. R., 2011, Response of cucumber (Cucumis sativus L.) to chemical fertilizers and bio-fertilizer. Vegetable Science., 38(2): 235-236.

Prabhakar, M., Hebbar, S. S. and Nair, A. K. 2010. Production technology of vegetable crops-A hand book. Indian Institute of Horticultural Research, Hessarghatta, Bangalore, Karnataka, pp 87-92.

Ram, J. P, Dwivedi, S. V. and Anand, R. K. 2013. Studies on effect of mulching and training on growth, yield and economics of pointed gourd (Trichosanthes dioica Roxb.). Asian. J. Hort., 8 (2): 645-647.

Rani, R., Nirala, S. K. and Suresh R. 2012. Effect of fertigation and mulch on yield of pointed gourd in calcareous soil of north Bihar. Environ and Ecol., 30(3A): 641- 645.

Rasul, M. G., Hiramatsu, M. and Okubo, H. 2004. Morphological and physiological variations in Kakrol (Momordica dioica Roxb.). J. Faculty. Agril., 49(1): 1-1.

Rodriguez, J. C., Shaw, N. L. and Cantliffe, D. J. 2007. Influence of plant density on yield and fruit quality of greenhouse-grown galia muskmelons. Hort. Technol., 17(4): 580-585.

Sharma, M. K., Negi, S., and Kumari, S. 2009. Effect of different growing media and fertigation levels on production of cucumber (Cucumis sativus L.) under protected conditions in the hills. Indian J. Agril. Sci., 79 (11): 853-856. 
Shinde, J. B., Malunjkar, B. D., Raut, R. S, Patil, P. D. and Thawal, D.W. 2010. Response of cucumber to fertigation under drip irrigation system. Bioinfolet-A Quarterly. J. Life. Sci., 7 (2): 161-164.

Sikarwar, P. and Hardaha, M. K. 2016. Effect of fertigation levels on growth, quality and yield of polyhouse cucumber (Cucumis sativus). Int. J.Agril. sci., 8 (43): 1863-1866.

Singandhupe, R. B., James, B. K., Antony, E., Nanda, P. and Behera, M. S.2007. Response of drip fertigation and mulching on growth and fruit yield of pointed gourd (Trichosanthes dioica). Indian. J. Agril. Sci, . 77 (1): 8-13.

Tisdale, S. L., Nelson, W. L. and Beaton, J. D. 1985. Soil fertility and fertilizers ( $4^{\text {th }}$ Ed.).
Mac Millan Pub. Co., Inc. New York, pp. 1733.

Ughade, S. R., Tumbare, A. D. and Surve, U. S. 2015. Effect of fertigation levels and schedules on growth, yield and quality of tomato (Solanum lycopersicum L.) under polyhouse. Int. J. Trop. Agric., 33(4): 27592764.

Wang, Y., Xie Z., Malhi., S. S., Vera, C. L., Zhang, Y. and Guo, Z. 2011. Effects of gravel-sand mulch, plastic mulch and ridge and furrow rainfall harvesting system combinations on water use efficiency, soil temperature and watermelon yield in a semiarid Loess Plateau of northwestern China. Agril. Water. Man., 101 (1): 88-92.

\section{How to cite this article:}

Ananda Murthy, H.C., A.K. Nair, M. Anjanappa, D. Kalaivanan, S. Shankara Hebbar and Laxman, R.H. 2020. Growth and Fruit Yield of Hybrid Ridge Gourd [Luffa acutangula L. Roxb] Arka Vikram in Relation to NPK Fertigation. Int.J.Curr.Microbiol.App.Sci. 9(06): 39543963. doi: https://doi.org/10.20546/ijcmas.2020.906.464 